\title{
Bioaccumulation of animal adenoviruses in the pink shrimp
}

\author{
Roger B. Luz ${ }^{1}$, Rodrigo Staggemeier ${ }^{1}$, Rafael B. Fabres ${ }^{1}$, Mayra C. Soliman ${ }^{1}$, \\ Fernanda G. Souza ${ }^{1}$, Raoni Gonçalves ${ }^{2}$, Ivone V. Fausto ${ }^{2}$, Caroline Rigotto ${ }^{1}$, \\ Larissa S. Heinzelmann ${ }^{1}$, Andréia Henzel ${ }^{1}$, Juliane D. Fleck ${ }^{1}$, Fernando R. Spilki ${ }^{1}$ \\ ${ }^{1}$ Laboratório de Microbiologia Molecular, Universidade Feevale, Novo Hamburgo, RS, Brazil. \\ ${ }^{2}$ Laboratório de Biologia e Microscopia, Universidade Federal do Rio Grande do Sul, Imbé, RS, Brazil.
}

Submitted: April 17, 2014; Approved: November 16, 2014.

\begin{abstract}
Adenoviruses are among the most promising viral markers of fecal contamination. They are frequently found in the water, sediment and soil of regions impacted by human activity. Studies of the bioaccumulation of enteric viruses in shrimp are scarce. The cities located in the northern coast of the lake systems in Southern Brazil have high urbanization and intensive farming rates, and poor sewage collection and treatment. One hundred $(\mathrm{n}=100)$ Farfantepenaeus paulensis pink-shrimp specimens and 48 water samples were collected from coastal lagoons between June 2012 and May 2013. Water samples were concentrated and the shrimp, mashed. After DNA extraction, samples were analyzed by real time polymerase chain reaction (qPCR) in order to detect and quantify viral genomes. Thirty-five percent of shrimp samples were positive for contamination, predominantly by avian adenoviruses. A total of $91.7 \%$ of water samples contained adenoviruses DNA, with the human form being the most frequent. Our results provided evidence of significant bioaccumulation of adenoviruses in shrimp, showing the extent of the impact of fecal pollution on aquatic ecosystems.
\end{abstract}

Key words: adenovirus, Farfantepenaeus paulensis, pink-shrimp, water quality, Northern Coast of Rio Grande do Sul.

\section{Introduction}

Crustaceans plays a crucial role in consumer-resource relationships in aquatic ecosystems. Damage to these populations may alter ecological functions and have a significant impact on the social, economic and health conditions of nearby communities (Seeliger and Odebrecht, 1996). Farfantepenaeus paulensis (Peréz-Farfante, 1967), known as the pink shrimp, is native to the Brazilian coast, and can be found along the entire coastline between northeastern Brazil and Argentina. Shrimp fishing, even at low levels, contributes significantly to the income of artisanal fishermen living in local communities and helps to maintain regional trade networks (Reis and D'Incao, 2000; Cotrim et al., 2007).

Crustaceans, clams and oysters can bioaccumulate enteric viruses and bacteria from surrounding water and sediment (Beuret et al., 2003). Shrimp and other crusta- ceans may also accumulate enteric viruses and bacteria through feeding on contaminated organisms, becoming pathogen vectors (DiGirolamo et al., 1972; Umesha et al., 2008). Moreover, it was postulated that organisms in contaminated water may carry viruses on their surface or bowels, acting as mechanical vectors (Stentiford et al., 2009). Shrimp contamination by poliovirus types 1 and 2 has been reported in Venezuela (Botero et al., 1996), while enterovirus contamination has been identified in India (Umesha et al., 2008). Although viruses transmitted by humans or other animals are unlikely to be able to replicate in shrimp cells, the consumption of undercooked contaminated shrimp may pose a serious health risk.

Adenoviruses (AdVs) belong to the Adenoviridae family. Contamination generally occurs by waterborne or fecal-oral transmission, making AdVs a promising viral indicator of fecal contamination in surface and groundwater (Thurston-Enriquez et al., 2003; Rigotto et al., 2010; Oli- 
veira et al., 2012; Vecchia et al., 2012). AdVs are nonenveloped and have double-stranded DNA, and are therefore more resistant to environmental degradation and water treatment than other contamination indicators (Tavares et al., 2005; Bofill-Mas et al., 2006; Jiang et al., 2007; Griffin et al., 2008). AdVs are the most prevalent human viruses in sewage and can be found in contaminated bodies of water throughout the year (Rigotto, 2010), although contamination is more frequent in temperate regions (Tavares et al., 2005). The main sources of water contamination are sewage leakage or discharge and urban or rural runoff. AdVs are often found in urban rivers (Tani et al., 1995; Castignollesa et al., 1997; Chapron et al., 2000), or polluted coastal waters (Puig et al., 1994; Pina et al., 1998; Jiang et al., 2001; Rigotto et al., 2010), where they may persist for up to four months (Lipp and Rose, 1997; Jiang et al., 2001). The annual risk of infection by consumption of contaminated water is of $0.9 \%$ for one infectious unit in 100 liters of water (Mena and Gerba, 2008), and although most infections are asymptomatic, AdVs can cause paralysis, meningitis, myocarditis, congenital heart defects, infectious hepatitis, ocular infections and gastroenteritis (Pina et al., 1998; Lenaerts et al., 2008). AdV levels can be used as indicators of water and food contamination and as a tool for the evaluation of fecal contamination patterns in different regions. AdVs cannot replicate outside the host cell and are highly species-specific, facilitating the identification of the sources of microbial contamination, and the implementation of corrective or mitigating measures (Field and Samadpour, 2007). In the southernmost state of Brazil, the presence of AdVs has been detected in sewage-contaminated surface waters in the state capital (Vecchia et al., 2012) and in contaminated groundwater in the countryside (Oliveira et al., 2012).

The Tramandaí, Armazém and Custódia Lagoons are part of the Tramandaí River basin, located in the Coastal Hydrographic Region of Rio Grande do Sul, in southern Brazil. The lagoon system is connected to the Atlantic Ocean by a small watercourse in the Tramandaí Lagoon. The Camarão River joins the Armazém and Custódia Lagoons. The Tramandaí and Armazém Lagoons are classified by the Luiz Roessler Environmental Protection Agency (Fundação Estadual de Proteção Ambiental Henrique Luiz Roessler; FEPAM) as brackish water type 2, while the Custódia Lagoon is classified as brackish water type 1 . The latter can therefore be used for recreational or fishing activities provided fecal coliform organisms are absent (FEPAM, 2000). Although the exact state of sanitation in the cities of Tramandaí, Imbé and Osório, which surround the lagoons, is unknown, the average shortfall in sewage treatment in Southern Brazil has been found to be as high as $82 \%$ (Clarke and King, 2006). At the time of writing, Imbé has no sewage collection system, and in Tramandaí, only $28 \%$ of the total sewage load is treated (SNIS, 2011). The disposal of untreated sewage into bodies of water can modify the levels of dissolved nutrients in the water, induce eutrophication and reduce local diversity (Seeliger and Odebrecht, 2010). The tributaries of the lagoons are also contaminated by domestic and agricultural runoff, creating a potential health hazard for the 100 to 200 thousand people who live in the area (SEMA, 2010; IBGE, 2011). Water contaminated with urban sewage may contain several waterborne pathogens, including bacteria, protozoa and viruses. The consumption of contaminated water or food and recreation in contaminated waters represents an especially serious risk for children, the elderly and the immunocompromised (Fong and Lipp, 2005). The lack of sanitation and land use guidelines may pose a serious impact on water quality and aquatic ecosystems (FEPAM, 2000). Other areas in the basin are also used for agriculture and livestock production (mostly cattle, swine and chicken). The lagoons are also the habitat of several avian species and serve as a resting place for migratory birds.

As a result of the poor sewage treatment and intensive disposal of untreated wastewater in their surrounding area, Brazilian lagoons may represent an ideal location for the study of fecal pollution. The study of these lagoons is especially relevant given the diversity of mammal, avian and aquatic species inhabiting the area. The aim of the present study was to investigate the potential bioaccumulation of adenovirus DNA in shrimp collected from the lagoon system.

\section{Material and Methods}

\section{Sampling sites}

Samples were collected from two shrimp fishing sites and ten water sampling sites in the Tramandaí, Armazém and Custódia Lagoons, located on the northern coast of the state of Rio Grande do Sul. Sites were delimited with the help of the Center for Coastal, Limnological and Marine Studies (CECLIMAR) of the Federal University of Rio Grande do Sul (UFRGS). Samples were collected by boat from the sites shown in Figure 1. CECLIMAR donated 50 $F$. paulensis shrimp collected from the Camarão River and Armazém Lagoons in April 2013, as well as 50 shrimp of the same species obtained from the estuary in 2011. Ten 500 -milliliter $(\mathrm{mL})$ samples of water were also aseptically collected at five time points between June 2012 and May 2013.

\section{Sample preparation}

The shrimp were fully macerated and stored at $-80{ }^{\circ} \mathrm{C}$ until processing. Approximately 1 gram of macerated tissue was diluted in $1 \mathrm{~mL}$ of Eagle's minimum essential medium (E-MEM), which was then vortexed and centrifuged for $10 \mathrm{~min}$ at $18,000 \times \mathrm{g}$.

Water samples were concentrated by adsorptionelution, as described by Katayama et al. (2002), with minor modifications. Briefly, $0.6 \mathrm{mg} \mathrm{MgCl}_{2}$ were added to each 


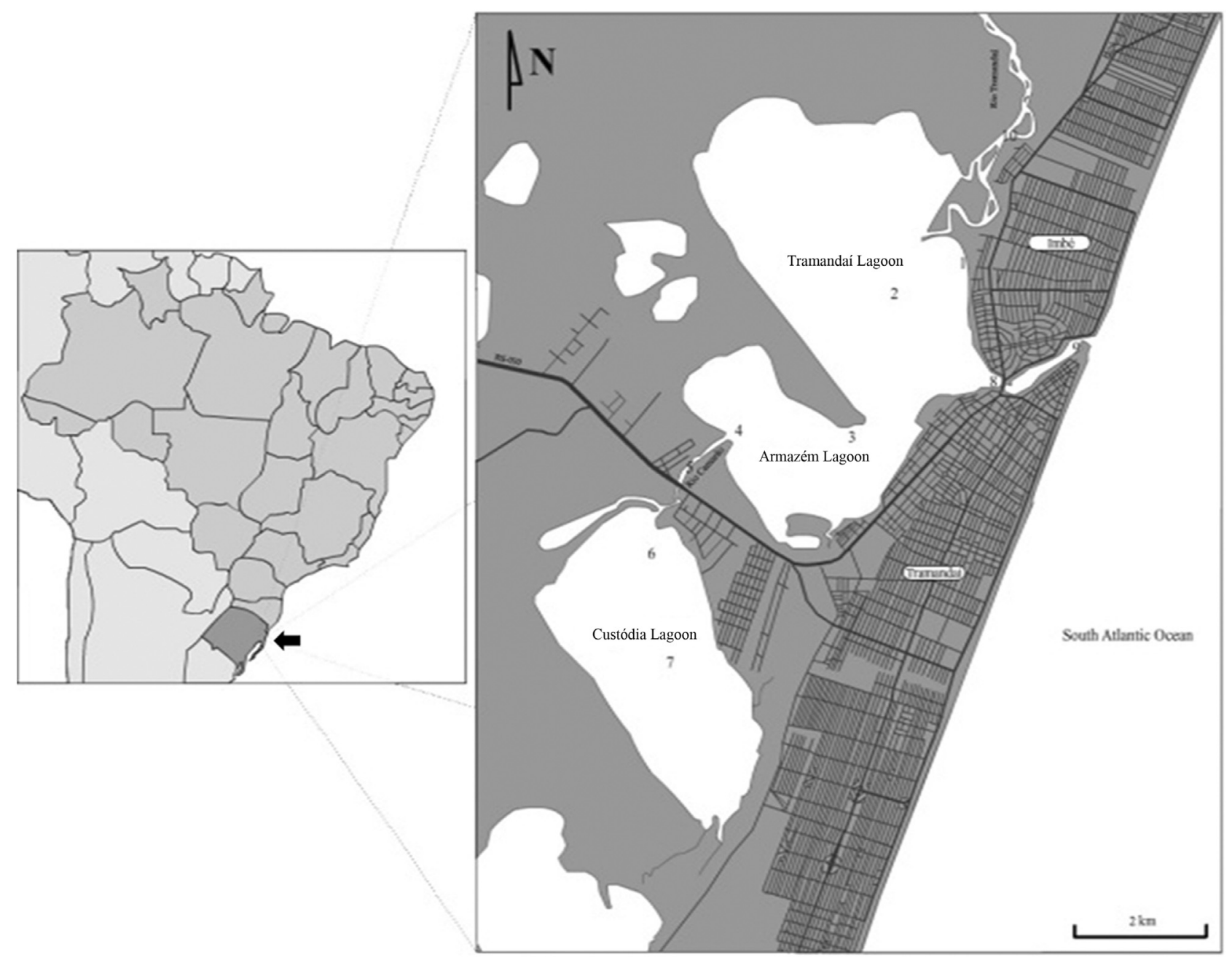

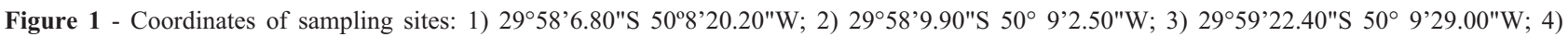
$\left.29^{\circ} 59^{\prime} 11.40^{\prime \prime} \mathrm{S} 50^{\circ} 10^{\prime} 27.70^{\prime \prime} \mathrm{W} ; 5\right) 29^{\circ} 59^{\prime} 28.30^{\prime \prime S} 50^{\circ} 10^{\prime} 47.50^{\prime \prime} \mathrm{W}$; 6) $30^{\circ} 0^{\prime} 14.80^{\prime \prime} \mathrm{S} 50^{\circ} 11^{\prime} 15.30^{\prime \prime} \mathrm{W}$; 7 ) $\left.30^{\circ} 0^{\prime} 54.30^{\prime \prime} \mathrm{S} 50^{\circ} 11^{\prime} 20.70^{\prime \prime} \mathrm{W} ; 8\right)$ $29^{\circ} 58^{\prime} 55.10^{\prime \prime} \mathrm{S} 50^{\circ} 8^{\prime} 2.50^{\prime \prime} \mathrm{W}$; 9) $29^{\circ} 58^{\prime} 36.30^{\prime \prime} \mathrm{S} 50^{\circ} 7^{\prime} 20.70^{\prime \prime} \mathrm{W}$; 10) $29^{\circ} 56^{\prime} 53.10^{\prime \prime} \mathrm{S} 50^{\circ} 7^{\prime} 57.40^{\prime \prime} \mathrm{W}$.

sample and $\mathrm{pH}$ was adjusted to $5 \pm 0.5$. The samples were filtered through negatively charged nitrocellulose membranes $\left(0.45 \mu \mathrm{m}, 47 \mathrm{~mm}\right.$ diameter; HA Millipore ${ }^{\circledR}$, Massachusetts, USA). Membranes were washed with $87.5 \mathrm{~mL}$ of 0.5 millimolar $(\mathrm{mM})$ sulfuric acid $\left(\mathrm{H}_{2} \mathrm{SO}_{4}\right)$ and $2.5 \mathrm{~mL}$ of $1 \mathrm{mM}$ sodium hydroxide. The final extract was neutralized with 12.5 microliters $(\mu \mathrm{L})$ of $\mathrm{H}_{2} \mathrm{SO}_{4}, 50 \mathrm{mM}$, and $12.5 \mu \mathrm{L}$ of Tris-EDTA 100x buffer. The filtrate was stored at $-80{ }^{\circ} \mathrm{C}$.

\section{Molecular techniques}

Viral DNA was extracted from concentrated water samples and the supernatant from the macerated tissue samples using a DNA/RNA extraction kit (Stratec ${ }^{\circledR}$, Berlin, Germany), according to manufacturer's instructions.

Two pairs of primers were used for quantitative polymerase chain reaction ( $\mathrm{qPCR}$ ) assay and high resolution melting analysis (HRM). For the detection of human (HAdV), canine (CAV), bovine (BAV), avian (AvAdV) and porcine (PoAdV) AdV, pan-specific adenovirus primers ADV-F1 (5'-CAGTGGTCGTACATGCACAT-3') and ADV-R1 (5'-TCGGTGGTGACGTCGTGG-3') at a concentration of 20 picomoles (pM) were used in the following reaction: a denaturation cycle at $95^{\circ} \mathrm{C}$ for $10 \mathrm{~min}$ ( $\mathrm{min}$ ), followed by 50 cycles of 20 seconds (s) at $95^{\circ} \mathrm{C}$, and a combined annealing/extension step at $58^{\circ} \mathrm{C}$ for $1 \mathrm{~min}$. Fluorescence data were collected during the annealing/extension step. After that, a denaturation curve was generated to confirm the specificity of amplification products (melting points between 55 and $95^{\circ} \mathrm{C}$ ). qPCR-HRM can be used to identify the genus of the viral host based on the guanine-cytosine content of the amplified fragment and DNA sequence and strand length, since even a single variation in a nitrogen base can affect the melting curve (Erali et al., 2008). The identity of final PCR products were confirmed by high resolution melting curves (HRM). The melting peaks of each species of $\mathrm{AdV}$ are as follows: HAdV (88 $\left.{ }^{\circ} \mathrm{C}\right), \operatorname{BAV}\left(85.5^{\circ} \mathrm{C}\right), \operatorname{PoAdV}\left(83.5^{\circ} \mathrm{C}\right), \operatorname{CAV}\left(82^{\circ} \mathrm{C}\right)$ and 
AvAdV $\left(80.5^{\circ} \mathrm{C}\right)$ (Fig. 2). Genotyping was confirmed in a subset of samples by direct sequencing (data not shown).

Given the overlap between the melting peaks of different AdV species, when more than one form of the virus was present, a separate reaction was used for the detection of HAdV. This reaction involved VTB2-F (5'-GAGACGTACTTCAGCCTGAAT-3') and VTB2-R (5'-GATGAACCGCAGCGTTCAA-3') primers at $20 \mathrm{pM}$, as described by Wolf et al. (2010), and was performed under the same time and temperature conditions as the remainder of the reactions described. However, in this procedure, the annealing temperature was lowered to $55^{\circ} \mathrm{C}$ and the number of cycles was reduced to 40 . HAdV had a specific melting peak of $86^{\circ} \mathrm{C}$.

In each run, no template control (NTC) and negative control samples were used to exclude contamination. Standard curves were used to determine the genome copies (gc) in each samples. Ten-fold serial dilutions of the control fragment from $10^{-1}$ to $10^{-5}$ starting at $6.01 \times 10^{7} \mathrm{gc} / 5 \mu \mathrm{L}$ (HAdV-5; VTB2 primer set) and $6.88 \times 10^{8} \mathrm{gc} / 5 \mu \mathrm{L}$ (HAdV-2; ADV primer set)were used in each reaction as positive controls. The mean coefficient of determination $\left(\mathrm{R}^{2}\right)$ of these reactions was 0.998 , their efficiency was $98.7 \%$ and the analytical sensitivity was $8-12$ genome copies per $1 \mu \mathrm{L} /$ reaction. Both sets of primers target a highly conserved region of the hexon gene. All reactions were run in duplicate using the Platinum ${ }^{\circledR}$ SYBR $^{\circledR}$ Green qPCR Super Mix-UDG (Life Technologies Corporation, Carlsbad, California 92008, USA) commercial kit. qPCR reactions was performed in a thermal cycler (iQ5 Bio-Rad, Biorad, Hercules, California 94547, USA) under the following conditions: each $25 \mu \mathrm{L}$ reaction contained $12.5 \mu \mathrm{L}$ of Mix, $5.5 \mu \mathrm{L}$ of ultrapure water (DNAse/RNAse free), $1 \mu \mathrm{L}$ of each primer $(20 \mathrm{pM})$ and $5 \mu \mathrm{L}$ of the nucleic acid extracted from each sample.

\section{Results and Discussion}

AdV contamination was detected in 35 (35\%) of the 100 samples collected from both fishing sites. AvAdV was present in 17 samples (17\%), BAV in $13(13 \%), \mathrm{CAV}$ in 7 $(7 \%)$ and PoAdV in $2(2 \%)$. An average of $5.8 \times 10^{4}$ genome copies $\left(3.31 \times 10^{2}-8.18 \times 10^{5}\right)$ were present per gram of tissue. HAdV was not found in any tissue samples with either primer set. For reasons which still remain unknown, HAdV may not accumulate in pink shrimp tissue, or may not be detectable by the methods used in the present study. This result may also suggest that these bodies of water may be less contaminated by human feces than animal waste, since the geometric mean of genome copies of $\mathrm{HAdV} / \mathrm{L}$ was lower than of other viruses.

AdVs were detected in 44 of the 48 (91.7\%) water samples collected. Contamination was present in at least

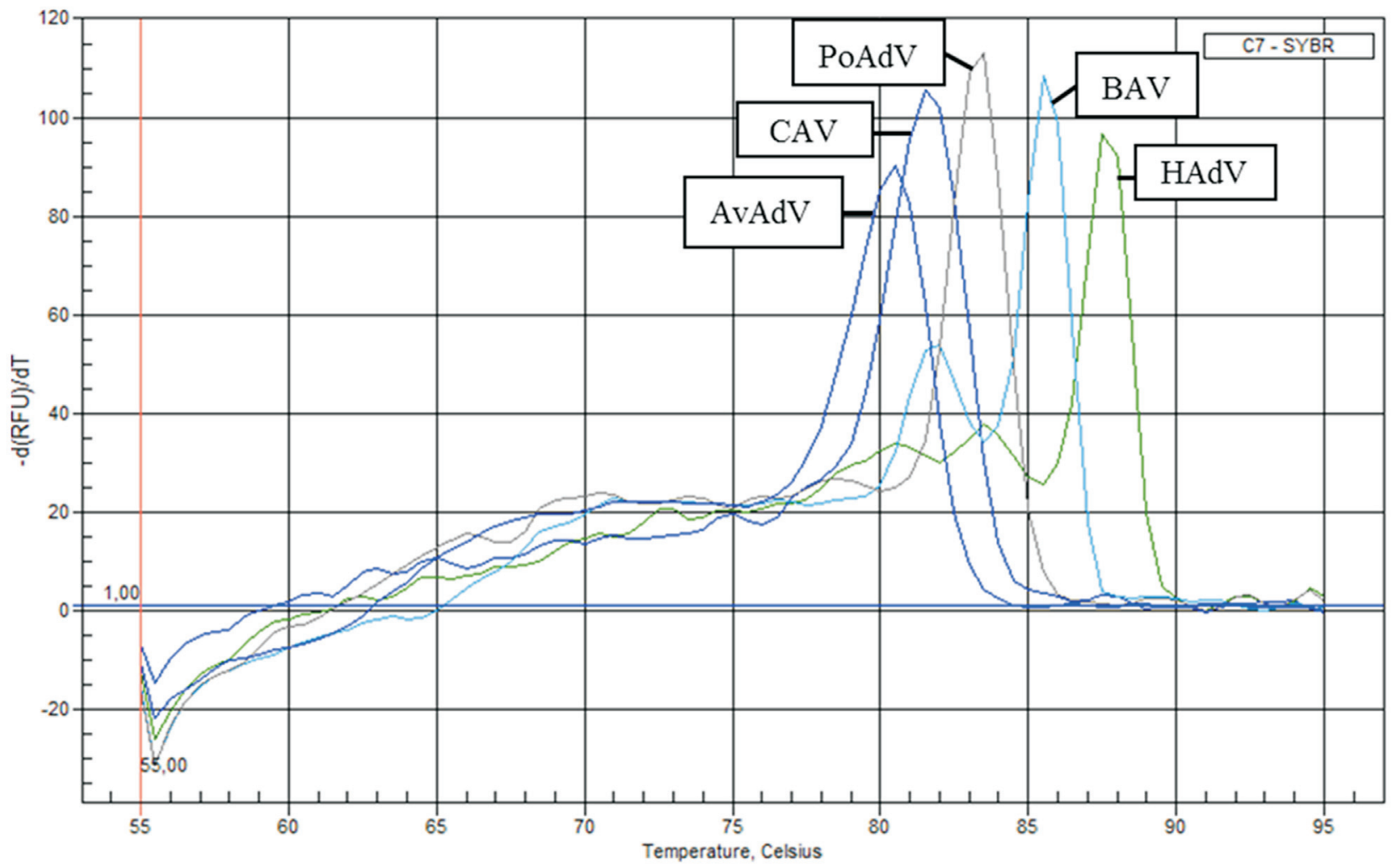

Figure 2 - High resolution melting curve for adenoviruses showing the melting peaks of control samples; AvAdV - unspecified avian adenovirus; CAV-2 - canine adenovirus type 2; PoAdV - unspecified porcine adenovirus; BAV - unspecified bovine adenovirus; HAdV - human adenovirus type 2. 


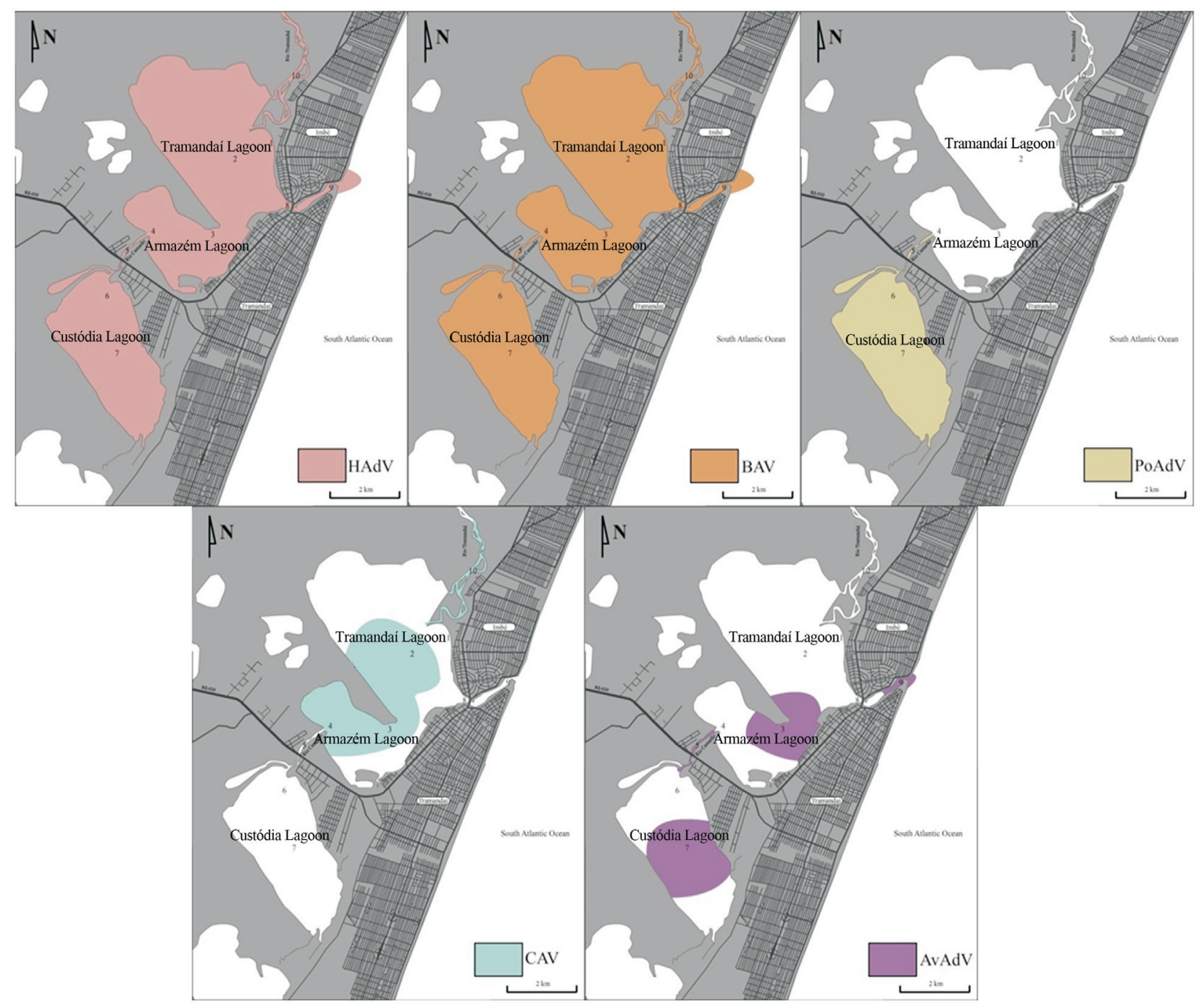

Figure 3 - Schematic representation of the distribution of human (HAdV), bovine (BAV), canine (CAV), avian (AvAdV) and porcine (PoAdV) adenovirus in the region studied.

one sample drawn from every site. The ADV-F1 and ADV-R1 primers identified adenoviral DNA in 38 samples (79.2\%), of which $23(47.9 \%)$ were by BAV, 7 (14.6\%) by HAdV, 5 (10.4\%) by AvAdV, 4 (8.4\%) by CAV and 4 $(8.3 \%)$ by PoAdV. The VTB2-F and VTB2-R primers revealed the presence of HAdV DNA in $28(58.3 \%)$ samples. When both primers were used, HAdV was detected in $64.6 \%$ (31 samples) of samples, with an average of $8.15 \mathrm{x}$ $10^{5}$ genome copies $\left(3.95 \times 10^{3}-1.09 \times 10^{9}\right)$ per liter. HAdV and BAV were found in all sampling sites. CAV was present in the Tramandaí Lagoon, Armazém Lagoon and Tramandaí River. AvAdV was found in the Armazém Lagoon, Custódia Lagoon, Camarão River and at the point where the lagoons connect to the ocean. PoAdV was detected in the Camarão River and Custódia Lagoon only.

The results are summarized in Tables 1 through 4 . A schematic representation of the viral distribution in the area studied is shown in Figure 3. Viral contamination was not statistically associated with climate variability, and did not differ between sampling sites and times (data not shown).

Although both enteroviruses and polioviruses have been found to accumulate in shrimp, the present study was the first to extract adenoviral DNA from shrimp and suggest that the pink shrimp F. paulensis may be a potential accumulator of these viruses and be a useful biomarker of fecal contamination in water. The detection rate $(35 \%)$ in the present study was near the mean of contamination rates found in studies of enteric viruses in shrimp in India (15\%) (Umesha et al., 2008) and Venezuela (49\%) (Botero et al., 1996). However, in these studies, untreated sewage was considered the main source of contamination. The organic matter from urban sewage, livestock waste, and wild-bird contamination dissolves in the water and can be consumed by penaeid shrimp, which carry the viruses on their surface. The use of shrimp as biomarkers of fecal contamination in water could facilitate the transportation and storage of sam- 
ples, although detection rates and genome copies were lower in shrimp tissue than in water samples. The prevalence of contamination by each type of AdV in shrimp tissue was as follows: AvAdV (17\%), BAV (13\%), CAV
(7\%) and PoAdV (2\%). AdV was detected in $91.7 \%$ of water samples, which were found to be contaminated by the human $(64.6 \%)$, bovine $(47.9 \%)$, avian $(10.4 \%)$, canine $(8.3 \%)$ and porcine $(8.3 \%)$ forms of the virus. While animal

Table 1 - Adenovirus contamination in water; HAdV - human adenovirus; BAV - bovine adenovirus; CAV - canine adenovirus; AvAdV - avian adenovirus; PoAdV - porcine adenovirus.

\begin{tabular}{|c|c|c|c|c|c|}
\hline Sampling site & HAdV (\%) & BAV (\%) & CAV $(\%)$ & AvAdV (\%) & PoAdV (\%) \\
\hline Site 1 - Tramandaí River Entrance & 60 & 60 & 0 & 0 & 0 \\
\hline Site 2 - Pontal & 80 & 80 & 20 & 0 & 0 \\
\hline Site 3 - Armazém Lagoon & 100 & 60 & 20 & 20 & 0 \\
\hline Site 4 - Camarão River Entrance & 40 & 60 & 20 & 0 & 0 \\
\hline Site 5 - Camarão River & 75 & 25 & 0 & 50 & 25 \\
\hline Site 6 - Custódia Lagoon & 60 & 20 & 0 & 0 & 40 \\
\hline Site 7 - Center of the Custódia Lagoon & 40 & 20 & 0 & 20 & 20 \\
\hline Site 8 - Garibaldi Bridge & 100 & 75 & 0 & 0 & 0 \\
\hline Site 9 - Barra Outfall & 60 & 60 & 0 & 20 & 0 \\
\hline Site 10 - Tramandaí River Embranchment & 40 & 20 & 20 & 0 & 0 \\
\hline
\end{tabular}

Table 2 - Mean genome copies of adenovirus per liter of water; HAdV - human adenovirus; BAV - bovine adenovirus; CAV - canine adenovirus; AvAdV - avian adenovirus; PoAdV - porcine adenovirus.

\begin{tabular}{|c|c|c|c|c|c|}
\hline Sampling site & HAdV & BAV & CAV & AvAdV & PoAdV \\
\hline Site 1 - Tramandaí River Entrance & $1.30 \times 10^{5}$ & $1.13 \times 10^{6}$ & 0 & 0 & 0 \\
\hline Site 2 - Pontal & $8.66 \times 10^{5}$ & $2.18 \times 10^{6}$ & $3.33 \times 10^{4}$ & 0 & 0 \\
\hline Site 3 - Armazém Lagoon & $9.02 \times 10^{4}$ & $1.37 \times 10^{7}$ & $1.02 \times 10^{8}$ & $2.82 \times 10^{8}$ & 0 \\
\hline Site 4 - Camarão River Entrance & $8.88 \times 10^{5}$ & $6.68 \times 10^{5}$ & $1.25 \times 10^{6}$ & 0 & 0 \\
\hline Site 5 - Camarão River & $1.32 \times 10^{6}$ & $4.95 \times 10^{6}$ & 0 & $6.46 \times 10^{6}$ & $5.53 \times 10^{7}$ \\
\hline Site 6 - Custódia Lagoon & $1.15 \times 10^{6}$ & $1.10 \times 10^{6}$ & 0 & 0 & $2.41 \times 10^{6}$ \\
\hline Site 7 - Center of the Custódia Lagoon & $1.84 \times 10^{5}$ & $5.18 \times 10^{6}$ & 0 & $1.09 \times 10^{9}$ & $1.94 \times 10^{7}$ \\
\hline Site 8 - Garibaldi Bridge & $1.69 \times 10^{5}$ & $2.50 \times 10^{6}$ & 0 & 0 & 0 \\
\hline Site 9 - Barra Outfall & $2.55 \times 10^{5}$ & $2.73 \times 10^{6}$ & 0 & $3.30 \times 10^{5}$ & 0 \\
\hline Site 10 - Tramandaí River Embranchment & $1.59 \times 10^{5}$ & $2.59 \times 10^{5}$ & $2.58 \times 10^{5}$ & 0 & 0 \\
\hline
\end{tabular}

Table 3 - Adenovirus contamination in shrimp; HAdV - human adenovirus; BAV - bovine adenovirus; CAV - canine adenovirus; AvAdV - avian adenovirus; PoAdV - porcine adenovirus.

\begin{tabular}{lccccc}
\hline Fishing site & HAdV (\%) & BAV (\%) & CAV (\%) & AvAdV (\%) & PoAdV (\%) \\
\hline Site 1 - Armazém Lagoon & 0 & 8 & 8 & 8 & 0 \\
Site 2 - Camarão River & 0 & 12 & 4 & 24 & 0 \\
Estuary 2011 & 0 & 16 & 8 & 18 & 4 \\
\hline
\end{tabular}

Table 4 - Mean genome copies of adenovirus per gram of tissue; HAdV - human adenovirus; BAV - bovine adenovirus; CAV - canine adenovirus; AvAdV - avian adenovirus; PoAdV - porcine adenovirus.

\begin{tabular}{lccccc}
\hline Fishing site & HAdV & BAV & CAV & AvAdV & PoAdV \\
\hline Site 1 - Armazém Lagoon & 0 & $2.95 \times 10^{3}$ & $6.05 \times 10^{3}$ & $1.23 \times 10^{5}$ & 0 \\
Site 2 - Camarão River & 0 & $1.03 \times 10^{5}$ & $1.18 \times 10^{4}$ & $3.81 \times 10^{4}$ & 0 \\
Estuary 2011 & 0 & $1.73 \times 10^{4}$ & $1.37 \times 10^{4}$ & $2.60 \times 10^{3}$ & $5.92 \times 10^{3}$ \\
\hline
\end{tabular}


viruses pose no risk for penaeid shrimp or human health, they can affect other species and be indicative of proximity to a source of pollution which could also contaminate bodies of water with other non-species-specific pathogens, such as bacteria, parasites and protozoa. All ecosystems require clean water, and enteric infections can lead to serious economic, social and environmental consequences for livestock or wild populations, rendering them more susceptible to other infections (Barardi et al., 2013). The avian AdVs detected in the present study may derive from poultry farms, since the cities surrounding the lagoons are estimated to produce approximately 15 thousand broilers (IBGE, 2010), or wild life. Of the 27 species of birds found in the lagoon system throughout the year, 10 use the lagoon as a food source (Ramos and Daudt, 2004), so that wild life contamination may have been partly responsible for our findings. All species of birds are susceptible to AvAdV contamination, and may shed the virus for more than 14 weeks after inoculation. Although most infections are subclinical, symptoms such as respiratory diseases, diarrhea, arthritis, inclusion body hepatitis, hydropericardium syndrome and egg drop syndrome have occasionally been found to occur (McFerran and Smyth, 2000). If not properly treated, the waste produced by the 6,000 swine and 30,000 heads of cattle in the cities of Tramandaí, Imbé and Osório, all of which are located in the Tramandaí River basin to the north of the Tramandai lagoon (IBGE, 2010), may contaminate both surface and groundwater. In winter months, cattle can also be found in open or unfenced urban areas, which are often used for complementary grazing (Ramos and Daudt, 2004). Cattle infected by the BAV may exhibit conjunctivitis, pneumonia, enteritis and polyarthritis (Flores, 2012). In swine, PoAdV may lead to diarrhea or respiratory complications (Hammond et al., 2003). CAV may be found in the feces of both wild and domestic canids, has a worldwide distribution and may cause infectious canine hepatitis and infectious canine tracheobronchitis, depending on the viral type (Flores 2012).

Enteric viruses are found frequently and at high levels in bodies of water contaminated by urban sewage or livestock waste. The prevalence of enteric viruses in surface water has been found to be very high in North America (Chapron et al., 2000) but somewhat lower in Brazil, where the rate of contamination by $\mathrm{AdV}$ ranges from $64.2 \%$ in the coastal region of the state of Santa Catarina (Rigotto et al., 2010 ) to $21.4 \%$ in the urban area of Porto Alegre (Vecchia et al., 2012). The primers used in the present study identified HAdV DNA in $64.6 \%$ of water samples. This finding shows the impact of poor waste management in the cities surrounding the lagoons on the water quality of the region. Approximately $80 \%$ of homes in the Tramandaí River basin have individual sewage disposal systems. In Osório and Tramandaí, solid waste repositories also contribute to water contamination, by leakage into rivers, streams and lakes. The maximum amount of HAdV DNA detected in water samples exceeded 10 million genome copies per liter. This number is alarming, considering that the basin supplies water to a population ranging from 100 to 200 thousand, in addition to domestic animals or wild life, and that $\mathrm{AdV}$ has an extremely low infectious dose (i.e. one infectious unit is already considered harmful) (Haas et al., 1993). Fecal contamination can also influence the concentration of organic matter, nitrates and phosphates, which, in excess, can be harmful to aquatic flora and fauna and lead to eutrophication (Seeliger and Odebrecht, 2010).

Further studies may wish to use amplicon sequencing to confirm the findings obtained with our pan-specific primers and perform phylogenetic analyses, especially of AvAdV, since the lagoons are home to many migratory bird species. Since no infectivity assay was performed, we cannot speak to the viability of the virus. However, AdV are known to be strong indicators of fecal contamination. Locations where adenoviruses are found, regardless of viability, may also be contaminated by other forms of the virus (Oliveira et al., 2012; Vecchia et al., 2012; Hartmann et al., 2013), different viral agents (Pina et al., 1998) or even other contaminants (Sidhu et al., 2013).

The present results emphasize the impact of untreated sewage and livestock waste on fragile aquatic ecosystems. There is a pressing need for more adequate biological and chemical markers of water quality, higher investments in sanitation and joint efforts from the government, industry and population to reduce the generation and inadequate disposal of waste.

\section{Acknowledgments}

RBL had a master's scholarship from FAPERGS/CAPES. FRS is a CNPq research fellow. Financial support was provided by the Fundação de Amparo à Pesquisa do Estado do Rio Grande do Sul (FAPERGS) and Conselho Nacional de Desenvolvimento Científico e Tecnológico (CNPq). This project was supported by CECLIMAR, UFRGS, Fundação Estadual de Pesquisa Agropecuária do Rio Grande do Sul (FEPAGRO Saúde Animal) and the Universidade Feevale.

\section{References}

Barardi CRM, Viancelli A, Rigotto C et al. (2013) Monitoring viruses in environmental samples. Int J Environ Sci Eng Res 3:62-79.

Beuret C, Baumgartner A, Schluep J (2003) Virus-Contaminated Oysters: a Three-Month Monitoring of Oysters Imported to Switzerland. Appl Environ Microbiol 69:2292-2297.

Bofill-Mas S, Albinana-Gimenez N, Clemente-Casares P et al. (2006) Quantification and Stability of Human Adenoviruses and Polyomavirus JCPyV in Wastewater Matrices. Appl Environ Microbiol 72:7894-7896.

Botero L, Montiel M, Portoa L (1996) Enteroviruses in shrimp harvested from contaminated marine waters. Int J Environ Health Res 6:103-108. 
Castignolles N, Petit F, Mendel I et al. (1998) Detection of adenovirus in the waters of the Seine River estuary by nested-PCR. Mol Cell Probes 12:175-180.

Chapron CD, Ballester NA, Fontaine JH et al. (2000) Detection of astroviruses, enteroviruses, and adenovirus types 40 and 41 in surface waters collected and evaluated by the information collection rule and an integrated cell culture-nested PCR procedure. Appl Environ Microbiol 66:2520-2525.

Clarke R, King J (2006) O Atlas da Água. Publifolha, São Paulo.

Cotrim DS, Miguel LA, Fernández-Baldor Á (2007) Sistemas Pesqueiros e a Pesca Artesanal: O caso de Tramandaí/RS. Congresso Brasileiro de Sistemas de Produção. Sociedade Brasileira de Sistemas de Produção, Fortaleza.

DiGirolamo R, Wiczynski L, Daley M et al. (1972) Preliminary Observations on the Uptake of Poliovirus by West Coast Shore Crabs. Appl Microbiol 23:170-171.

Durand SV, Lightner DV (2002) Quantitative real time PCR for the measurement of white spot syndrome virus in shrimp. J Fish Dis 25:381-389.

Erali M, Voelkerding KV, Wittwer CT (2008) High resolution melting applications for clinical laboratory medicine. Exp Mol Path 85:50-58.

FEPAM - Fundação Estadual de Proteção Ambiental Henrique Luiz Roessler (2000) Diretrizes Ambientais para o Desenvolvimento dos Municípios do Litoral Norte. Cadernos de Planejamento e Gestão Ambiental n. 1. FEPAM, Porto Alegre.

Field KG, Samadpour M (2007) Fecal source tracking, the indicator paradigm, and managing water quality. Water Res 41:3517-3538.

Flores EF (2012) Virologia Veterinária: Virologia Geral e Doenças Víricas. UFSM, Santa Maria.

Fong TT, Lipp EK (2005) Enteric Viruses of Humans and Animals in Aquatic Environments: Health Risks, Detection, and Potential Water Quality Assessment Tools. Microbiol Mol Biol Rev 69:357-371.

Griffin JS, Plummer JD, Long SC (2008) Torque teno virus: an improved indicator for viral pathogens in drinking waters. Virol J 5:1-6.

Haas CN, Rose JB, Gerba C et al. (1993) Risk assessment of virus in drinking water. Risk Anal 13:545-552.

Hammond JM, Jansen ES, Morrissy CJ et al. (2003) Protection of pigs against 'in contact' challenge with classical swine fever following oral or subcutaneous vaccination with a recombinant porcine adenovirus. Virus Res 97:151-157.

Hartmann NM, Dartscht M, Szewzyk R et al. (2013) Monitoring of adenovirus serotypes in environmental samples by combined PCR and melting point analyses. Virol J 10:1-9.

IBGE - Instituto Brasileiro de Geografia e Estatística (2010) Produção da Pecuária Municipal 38:1-65.

IBGE - Instituto Brasileiro de Geografia e Estatística (2011) Censo Demográfico 2010.

Jiang SC, Chu W, He JW (2007) Seasonal Detection of Human Viruses and Coliphage in Newport Bay, California. Appl Environ Microbiol 73:6468-6474.

Jiang S, Noble R, Chu W (2001) Human Adenoviruses and Coliphages in Urban Runoff-Impacted Coastal Waters of Southern California. Appl Environ Microbiol 67:179-184.

Katayama H, Shimasaki A, Ohgaki S (2002) Development of a virus concentration method and its application to detection of enterovirus and Norwalk virus from coastal seawater. Appl Environ Microbiol 68:1033-1039.

Lenaerts L, De Clercq E, Naesens L (2008) Clinical features and treatment of adenovirus infections. Rev Med Virol 18:357374.

Lipp FK, Rose JB (1997) The role of seafood in foodborne diseases in the United States of America. Rev Sci Tech 16:620-640.

McFerran JB, Smyth JA (2000) Avian adenoviruses. Rev Sci Tech OIE 19:589-601.

Mena KD, Gerba CP (2008) Waterborne Adenovirus. Rev Environ Contam T 198:133-167.

Monteiro GS, Fleck JD, Kluge M et al. (in press). Adenoviruses of canine and human origins in stool samples from a free-living pampas foxes (Lycalopex gymnocercus) and crab-eating foxes (Cerdocyon thous) in São Francisco de Paula, Rio dos Sinos basin. Braz J Biol (in press).

Nunan LM, Poulos BT, Lightner DV (2000) Use of polymerase chain reaction (PCR) for the detection of infectious hypodermal and hematopoietic necrosis virus (IHHNV) in penaeid shrimp. Mar Biotechnol 2:318-328.

Oliveira LK, Fleck JD, Comerlato J et al. (2012) Enteric viruses in water samples from Brazilian dairy farms. Agr Water Manage 111:34-39.

Pina S, Puig M, Lucena F et al. (1998) Viral Pollution in the Environment and in Shellfish: Human Adenovirus Detection by PCR as an Index of Human Viruses. Appl Environ Microbiol 64:3376-3382.

Puig M, Jofre J, Lucena F et al. (1994) Detection of adenoviruses and enteroviruses in polluted waters by nested PCR amplification. Appl Environ Microbiol 60:2963-2970.

Ramos LA, Daudt RB (2004) Avifauna urbana dos balneários de Tramandaí e Imbé, litoral norte do Rio Grande do Sul. Biotemas 18:181-191.

Reis EG, D'Incao F (2000). The present status of artisanal fisheries of extreme Southern Brazil: an effort towards community-based management. Ocean Coast Manage 43:585-595.

Rigotto C, Victoria M, Moresco V et al. (2010) Assessment of adenovirus, hepatitis A virus and rotavirus presence in environmental samples in Florianopolis, South Brazil. J Appl Microbiol 109:1979-1987.

Seeliger U, Odebrecht C (2010). O Estuário da Lagoa dos Patos Um Século de Transformações. U. Seeliger. FURG, Rio Grande.

Seeliger U, Odebrecht C, Castello JP (1996) Subtropical Convergence Environments: The Coast and Sea in the Southwestern Atlantic. Springer, New York.

SEMA - Secretaria do Meio Ambiente (2010) Relatório Anual de Recursos Hídricos. Secretaria do Meio Ambiente, Estado do Rio Grande do Sul, Porto Alegre, 168 p.

Sidhu JPS, Ahmed W, Gernjak W et al. (2013) Sewage pollution in urban stormwater runoff as evident from the widespread presence of multiple microbial and chemical source tracking markers. Sci Total Environ 463-464:488-496.

SNIS - Sistema Nacional de Informações sobre Saneamento (2011) Diagnóstico dos Serviços de Água e Esgotos. Secretaria Nacional Ambiental do Ministério das Cidades, Brasília, $164 \mathrm{p}$.

Stentiford GD, Bonami JR, Alday-Sanz V (2009). A critical review of susceptibility of crustaceans to Taura syndrome, Yellowhead disease and White Spot Disease and implica- 
tions of inclusion of these diseases in European legislation. Aquacult 291:1-17.

Tani N, Dohi Y, Kurumatani N et al. (1995) Seasonal distribution of adenoviruses, enteroviruses and reoviruses in urban river water. Microbiol Immunol 39:577-580.

Tavares TM, Cardoso DDP, Brito WMED (2005) Vírus entéricos veiculados por água: aspectos microbiológicos e de controle de qualidade da água. Rev Patol Trop 34:85-104.

Thurston-Enriquez JA, Haas CN, Jacangelo J et al. (2003) Inactivation of Feline Calicivirus and Adenovirus Type 40 by UV Radiation. Appl Environ Microbiol 69:577-582.

Umesha KR, Bhavani NC, Venugopal MN et al. (2008). Prevalence of human pathogenic enteric viruses in bivalve mol- luscan shellfish and cultured shrimp in south west coast of India. Int J Food Microbiol 122:279-286.

Vecchia AD, Fleck JD, Comerlato J et al. (2012) First description of Adenovirus, Enterovirus, Rotavirus and Torque teno virus in water samples collected from the Arroio Dilúvio, Porto Alegre, Brazil. Braz J Biol 72:1-7.

Wolf S, Hewitt J, Greening GE (2010) Viral Muliplex Quantitative PCR Assays for Tracking Sources of Fecal Contamination. Appl Environ Microbiol 76:1137-1149.

Associate Editor: Cynthia Canêdo da Silva

All the content of the journal, except where otherwise noted, is licensed under a Creative Commons License CC BY-NC. 